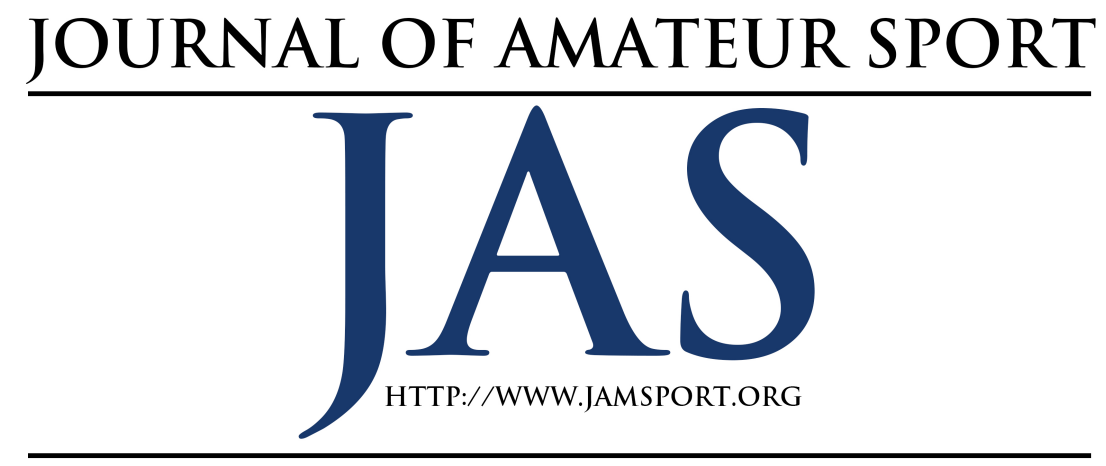

\title{
Not Going Pro: On Seeking Lasting Returns from College Sports
}

\author{
Matthew I. Horner \\ Neal Ternes \\ Christopher M. McLeod \\ Florida State University
}

\begin{abstract}
The National Collegiate Athletic Association (NCAA) clearly states there are many favorable qualities derived from sport participation that benefit those "who go pro in something other than sports." However, the ability of collegiate athletics to deliver on the promise of attributable long-term value is rarely questioned. In this study involving former NCAA Division I student-athletes, the authors examined whether participation can be regarded as an investment and how student-athletes perceive the returns thus derived. Adapting and extending Becker's (1962) theory of human capital investment to sport participation, the authors probed participants' experiences for evidence of investment thinking and lasting benefits in corporeal, economic, social, and cultural varieties. The findings support the notion that participation in collegiate athletics can be broadly defined as investment, but not in accordance with the claims made by the NCAA or the long-term utility maximizing rationale assumed by neoclassical economists. Furthermore, much like their nonathlete counterparts, high costs of participation, inherent uncertainty and risk, and unreliable information confound athletes' decision-making and blur the distinction between consumption in the present and investing for the future.
\end{abstract}

I

n 2007, the National Collegiate Athletic Association (NCAA) launched a branding campaign comprised of several public service announcements (PSAs) and a new website. The televised PSAs included a tagline that has since become quite well-known to advocates and critics of college sport alike: "There are over 380,000 student athletes, and most of us go pro in something other than sports" (NCAA, 2007). Architects of the campaign indicated they were specifically targeting potential student-athletes and their parents with the new marketing strategy. According 
to Penny Baldwin, managing director of $\mathrm{Y} \& \mathrm{R}$ - the marketing firm hired by the NCAA, the goal of the campaign was to highlight the "many intangible qualities student-athletes gain from their NCAA experience that stay with them throughout their lives" (NCAA, 2007). Dennis Cryder, then the NCAA senior vice-president for branding and communications, added, "many people do not realize the profound positive effects that college sports have" (NCAA, 2007).

Although the wording has changed, the refrain endures in the NCAA's current marketing materials. The following phrase was recently taken from the NCAA's website: "For the rest [not going pro], the experiences of college athletics and the life lessons they learn along the way will help them as they pursue careers in other fields" (NCAA, 2015a). The narrative espoused by the NCAA suggests that college sports definitively endow participants with certain favorable qualities.

The NCAA's statements are voiced in a time when universities are facing retrenched funding from state and federal sources, and are increasingly turning towards austerity policies and competitive profit-generating strategies to make ends meet (Aronowitz, 2000; Giroux, 2013; Washburn, 2008). The cumulative outcome of such an approach to higher education has been the emergence of what Henry Giroux (2007) called the "corporate university model" and its concomitant effects, including: skyrocketing costs in undergraduate education, the substitution of on-the-job training for education, an increased reliance on nontenured faculty and graduate students as instructors, and increased private and military intrusion into the research and educational prerogatives of public universities. The sum total of the policies of higher education's present political milieu has been a depreciation of educational quality for students despite rapidly inflating costs for undergraduate studies (Aronowitz, 2000; Giroux, 2007; Tuchman, 2009). Caught in this morass is the student body, treated as a disposable commodity in the race to accumulate private wealth through higher education (Giroux, 2014).

At the same time when the corporate university is giving less to students, the NCAA and popular discourse are telling students that tertiary education and extracurricular activities are investments. College athletes are uniquely positioned in this strange relationship in the sense that they do not just consume college life, but in many ways produce it: in terms of the "public goods" of college teams, the surpluses from revenue-generating sports, and the elusive "Flutie effect" of increased, post-victory, student applications (see Bass, Newman, \& Giardina, 2013; Sperber, 2000). Moreover, Wolverton, Hallman, Shifflett, and Kambhampati (2015) observed that over the last decade, increased subsidies for NCAA Division I athletics were primarily generated from higher student fees paid by non-athletes despite the reality of climbing tuition and deteriorating educational quality.

The aim of this study is to extend the line of critical inquiry by interrogating the contemporary practice of college sports in order to understand the real utility provided to participants and reconcile the enthusiastic claims made by the NCAA. To target the actual long-term value afforded to participants, former NCAA Division I 
student-athletes are interviewed. Former student-athletes are important because they can elucidate both the experience of being a college athlete and life after college sports.

Drawing from the concept of human capital investment as theorized by the Nobel Prize winning economist Gary Becker (1962), as well as critiques of the homo economicus model offered by the French historian and political philosopher Michel Foucault (2004/2008), the participants were asked to evaluate the treatment of athletic participation as a type of personal investment and describe their perceived return on investment (ROI) attributable to sport. Our findings support the relevance of ROI analysis to college sport, but also elucidate problems with using criteria that do not account for the equivocal returns of participation. Furthermore, our analysis prompts us to question the statements made by the NCAA and the role of intercollegiate athletics within the corporate university model (Giroux, 2007).

\section{Corporeal Investment and Productive Capital}

In the early 1960s, Theodore Schultz (1961) and Gary Becker (1962) sought to explain why people work. Both scholars concluded that the objective of work is to earn a wage. This wage is the return on one's labor-an income (or interest) on a particular form of capital. Schultz (1961) and Becker (1962) reasoned that the capital of which the wage is the income is the set of physical and psychological factors, which make someone able to do a particular kind of work. Thus, labor is a kind of capital, embodied as skill and ability, representative of the potential for work and the source of future income. Consequently, the concept of buman capital was born.

The shift in thinking about the body as a form of capital opened up previously private matters of the self and the family to a host of economic analyses and sparked a debate about the consequences of such thinking. Paraphrasing Foucault's (2004/2008) conception of the neoclassical position, human capital is inseparable from the person who possesses it - the capacity to work, a skill, or an ability is indistinguishable from the person who is skilled and can do a particular thing. In other words, labor as capital is instinctively buman. Furthermore, because a worker has a lifespan and length of time in which his or her labor can be used in a productive capacity, human capital itself ages and has an eventual obsolescence. Therefore, the modern worker is a sort of machine, producing a stream of earnings over its lifespan. It is in this "machine-stream ensemble" that the worker is conceived not as the subject of labor-power as Marx argued, but rather as a conception of "capital-ability" - that is, the worker as a sort of "enterprise for himself (sic)" (Foucault, 2004/2008, p. 224-225).

Accordingly, a worker can be viewed as an entrepreneur-no longer merely a subject of capitalist power over labor, but a worker as a rational enterprise in and of himself or herself. From useful abstraction to wayward economic model, a variety of notable scholars including John Stuart Mill, Thorstein Veblen, Max Weber, John Maynard Keynes, Karl Polanyi, Michel Foucault, and many others have referred to this self-sustaining, omnipotent entrepreneur-of-the-self as homo economicus. 
The treatment of laborers not as individual people, but as commercial enterprises by neoclassical economists allowed for the rationalization, systematization, and quantification of a society and an economy (see Foucault, 2004/2008; Miller \& Rose, 2008). The shift in thinking, regarding the body as a site of potential capital accumulation, alters the way an education, skill, or ability figures into the microeconomies of individuals and families, and explains how these traits (or the pursuit thereof) can be quantified and evaluated in terms of a cost/benefit or risk/return.

In order to conceive of human skills, attributes, and capacities as capital, it presupposes that human activity and training are investments. In economics, investment is understood as forgoing consumption in the present in order to realize consumption in the future. In sport, investment has commonly been conceptualized as practice, whereby shortterm sacrifices of time and physical effort are necessary to prepare for athletic performances in the future. For instance, Ericsson (2007; Ericsson, Krampe, \& Tesch- Römer, 1993) has written extensively on deliberate practice - a task that requires effort, has no monetary rewards, and is not inherently enjoyable, but is required for achieving expertise in sport.

Extending and broadening investment analyses to sport participation is not uncommon nowadays, although it has elicited some lamentations. For instance, Newman (2014), commenting on the economization of sport, stated:

Business and markets did not create running and jumping, they valorized them. A young child who swings a bat or dives into a swimming pool does so not necessarily to become, or be made into, a consumer (or a commodity, a celebrity, or a brand). (p. 611, emphasis in original)

Indeed, college student-athletes may not regard themselves as commercial enterprises, but under the collegiate model of marketized sport, which has existed for at least the last 50 years (Oriard, 2012), such a state may be unavoidable. When the market reality of modern-day college sport is coupled with the popular discourse concerning participation, application of homo economicus to the student-athlete as an abstracted ideal-type appears almost natural. Instead of fighting this idealization, we embrace the notion that student-athletes may regard participation as a form of personal investment and turn our focus towards evaluating the promise of significant and lasting benefits.

The investment decision is crucial to assessing the verity of investment as a framework for understanding college sport participation. In order for a decision to be classified as an investment, the actor must have some sense of information, uncertainty, and risk (Black, 1986; Callon, Lascoumes, \& Barthe, 2001/2009). More specifically, if investment is consumption delayed into the future, then the actor who invests is one who confronts the uncertainty of the future, and therefore the uncertainty of their future consumption.

To deal with this uncertainty, an actor acquires information. Information allows an actor to treat the uncertain future as risk; that is, investors use information to make uncertainty calculable and actionable. The quality of information, and the manner with 
which information is sourced and given, is therefore of central importance to investment in sport.

\section{Personal Investment in Sport}

Physical activity, exercise, and sport have been approached by scholars as a type of personal investment from a variety of perspectives and disciplines including physiology, psychology, sociology, and economics. Together, this research spans the physical and social-psychological effects of sport participation as well as some of the many macro-/microeconomic aspects of marketized sport. Physical education, kinesiology, and health studies researchers, for instance, have studied the investment of time and effort against the ability of various forms of physical activity to generate favorable physiological and psychological effects for participants (see Duda \& Tappe, 1988; Ostrow, 1984; Smith \& Serfass, 1981). In this vein, some scholars have explored the motivations, extent, and meaning ascribed to participation (Gray-Lee \& Granzin, 1997), while others have focused on elite sport participation and the ideal mix of training to bring about superior performance (Wall \& Cote, 2007). Still, others contend that social well-being as an outcome of participation is underresearched compared to other fields in the health sciences (see Fox, 1997, 1999; Miller \& Hoffman, 2009; Reinboth \& Duda, 2006).

Participation, particularly in elite organized sports, is increasingly viewed as a personal economic investment where costs and value are treated as pecuniary variables. Indeed, economists have approached sport as a new (and unique) frontier to apply classic investment techniques and financial assessment tools. Treating sport as a form of investment, economists have applied marginal revenue product (MRP) calculations, labor marketability assessments, and reviews of long-term economic well-being to assess the economic value of elite athletes at the high school, college, and professional levels (Barron, Ewing, \& Waddell, 2000; Beamon, 2008; Eide \& Ronan, 2000; Ewing, 1995, 1998, 2007; French, 2004; Long \& Caudill, 1991; Sack \& Thiel, 1979; Staurowsky, 2013). Other participation-related topics studied by economists include player compensation strategies and management relations (e.g., Fort \& Quirk, 1995; Rosen \& Sanderson, 2001), social determinants (e.g., Hoffman, Ging, \& Ramasamy, 2002), industrial organization (e.g., Neale, 1964; Szymanski, 2003), economic impact (e.g., Baade \& Matheson, 2001; Siegfried \& Zimbalist, $2000)$, and the practice and influence of sports gambling (e.g., Forrest \& Simmons, 2003; Zuber, Gandar, \& Bowers, 1985).

Upon review of the cumulative body of literature, it is apparent there has been a shift in thinking concerning the assessment of value derived from sport participation. Thinking of sport as an investment, especially when the corporeality of sport participation is converted into economic units of analysis, introduces (a) a rationale requiring $\mathrm{ROI}$ analysis to justify the expenditure of resources (similar to other types of financial investments), and (b) a particular set of criteria against which to measure ROI. The ROI metric is most often accredited to an extension of Kirkpatrick's (1977) taxonomy for training program evaluation, later solidified by 
Phillips (1997) as a way to calculate pay-off and demonstrate accountability by "following a logical, rational approach" (p. 2). In other words, by emphasizing the financial costs of training and development programs (as investment), the need arises to attribute direct returns to the expenditure of those resources.

Thinking in terms of cost/benefit necessitates the fabrication of evaluative criteria so that ROI analyses may be conducted. Unfortunately, the criteria selected are often arbitrary, vague, or cater to special interests, challenging the creation of an unbiased or objective ROI assessment sought in the first-place. Although ROI analysis may be applicable to sport participation, some resources invested (e.g., time, effort, and talent) are not easily quantifiable and the returns for non-premier athletes often lack attributable economic impact. For instance, it is more feasible to calculate the financial pay-off for those who can see a direct effect of their investment (e.g., elite or professional athletes who generate measurable financial returns for an organization or earn a wage for their participation) than the majority of those whose economic returns from sport participation are more subtle or uncertain.

\section{Short v. Long-Term Returns}

Efforts made by the NCAA and member institutions to incorporate protections for student-athletes-in other words, to guarantee long-term returnshave missed their mark (Smith, 2011). Indeed, NCAA reform is nothing new as "criticism of priorities and practices in intercollegiate sports, and thus an implicit call for reform, is nearly as old as college sports themselves" (Oriard, 2012, p. 4). However, as Oriard indicates many of the protocols enacted as a result of reform have ultimately shifted institutional concern for student-athletes away from their long-term well-being in favor of operational flexibility and short-term profitability.

Institutionalization of the nearsightedness plaguing collegiate athletics has been assisted by the establishment of academic progress and graduation metrics which have drawn considerable criticism for being poorly designed, inadequate, and easy to manipulate (Cusack, 2007; LaForge \& Hodge, 2011; Oriard, 2012; Wolverton, 2007). The metrics used by the NCAA today-namely, the Federal Graduation Rate (FGR), Graduation Success Rate (GSR), and Academic Progress Rate (APR) - to measure the scholastic success of student-athletes focus exclusively on "academic progress" with a terminal limit set at graduation.

Though parading as academic reform, these gestures overwhelmingly favor the interests of university athletic departments as employers of student-athlete laborlabor with only four-years of useful productivity defined by NCAA eligibility rules. Under the current regime, administrators need to be near-sighted to focus on academic progress, leaving student-athletes' long-term well-being to the amorphous "merits of participation." Effectively, athletic departments that profit from student-athlete labor are only required to "progress" them towards an academic degree and are relieved of any substantial responsibility for their long-term well-being.

LaForge and Hodge (2011) argue that APR and GSR make it possible for 
universities to adopt a "hands-off" or passive approach to student-athletes, using the metrics in ways that were never intended. While this treatment seems to put student-athletes on equal footing with the rest of the student-body, the student-athlete must still reconcile their massive investment in extracurricular athletic activities.

Troubling still, with the enormous pressure of superior athletic performance levied on student-athletes and those on whom they depend most for support and guidance (namely, coaches and administrators), a quality academic experience is often the first thing to be compromised. Student-athletes may progress towards degree completion or even graduate from college, but the value of the degree conferred, relevance of the experience conveyed, and utility of the skills mastered cannot be assumed. In sum, such a near-sighted concern for eligibility, academic progress, and quantitative metrics work together to obfuscate the true value of the collegiate student-athlete experience, especially when projected over an extended period of time.

Institutional protections for studentathletes are further handicapped by aggressive recruiting practices, year-round athletic schedules, and scholarships limited to one-year renewable contracts, each of which inundate the utility of participation with uncertainty. Today's student-athlete is in a precarious position-although they may be the functional unit of college sports, they are given no guarantees for their efforts. That being said, it is no small feat to count oneself among the ranks of NCAA Division I student-athletes as only $6 \%$ of high school athletes go on to compete for NCAA schools (NCAA, 2015a). Talent, practice, and money are the most obvious resources needed to transform an energetic youth into a college student-athlete. While talent is difficult to quantify, the costs of participation in terms of time and money are more visible.

Although there is much variation, youth sport participants, especially those most likely to compete in college, spend several hours each day (sometimes more than once a day, six or seven days a week) at practice or in competition. In economic terms, the cost of coaching and equipment fees alone (not including travel and specialty training camps) run between one-hundred to nearly one-thousand dollars per month (Kids Play USA, 2015). Private lessons push this figure upwards and, though most sports have a primary season, participation is likely to span all twelve months of the year. It is difficult to avoid the stress caused by such a high-value investment, notwithstanding the opportunity costs associated with commitment to competitive sports, emphasizing the need for participants to make the investment pay off.

Although there may be a need to justify the various costs, the developmental potential of sport participation (especially at the elite level) is increasingly uncertain and contingent (Coakley, 2006, 2011). Moreover, there is a tacit escalation of commitment corresponding with higherlevels of athletic competition (see Oriard, 2012; Smith, 2011; Watterson, 2005). In Division I college sports (the highest level of non-professional athletic competition in the U.S.), both the direct costs of participation and indirect (opportunity) costs of forgone value provided by alternative investments are likely to be high. 
Thus, given the high total cost of investment, questionable developmental and vocational potential, and contradicting institutional and popular discourses concerning participation, an investment analysis (with particular concern for ROI) is especially relevant. What we hope to contribute to the research on college sport participation through this study is an essential understanding of the long-term value afforded to participants who invest immensely in their discipline, but whose contributions are not easily quantifiablenamely, college student-athletes "who go pro in something other than sports."

\section{Assessing ROI after College Sports}

The challenge of ROI analysis is to link the pay-off to the investment. Although the formula can become quite complicated, the basic method for calculating ROI is to subtract the cost of an activity from the direct benefits of the activity (Grant, 2012). However, difficulty arises in precisely defining the costs and benefits, which can vary depending on what criteria are selected for the analysis. In the case of sport participation, this complexity is manifest in the myriad ways to conceptualize investment, multiple currencies of exchange, and subtle types of returns. The ROI criteria used in this study were drawn from an expanded version of the homo economicus model of human capital investment, accounting for a broad spectrum of possible outcomes.

Drawing from the works of Becker (1962), Bourdieu (1986, 1989, 2005), and Coleman (1988), four types of capital were used as theoretical moorings for our inquiry, including: buman, cultural, economic, and social capital. Human capital is created by training people to improve or acquire skills and capabilities that enable them to perform in new ways (Becker, 1962; Coleman, 1988; Schultz, 1961). Cultural capital refers to learned norms and values (signified by qualifications, customs, and artifacts) acquired through education, group memberships, and organizational associations (Bourdieu, 1986, 2005). In the Marxist tradition, economic capital is the value achieved by owning the means of production, either in a monetized or commodified form (Bourdieu, 1986, 2005). Social capital refers to the quality and totality of relationships between actors (via group membership and social networks) and the mutual cognition and recognition of the reciprocal nature of those relationships (Bourdieu, 1986, 2005; Coleman, 1988).

Furthermore, Bourdieu (2005) argued that what makes capital valuable to its possessor is its ability to be transformed or exchanged for something else. Therefore, we anticipated that our participants may be able to reflect on costs and returns from participation in two ways: (a) direct accumulation or dispossession of human, cultural, economic, or social capital from sport participation, or (b) indirect transformation of sport participation and capital derived from sport participation into other forms of capital.

\section{Method}

In order to understand the ways in which student-athletes perceive their college sport participation as a form of personal investment (or on the contrary, the reasons they do not), we designed a qualitative phenomenological study during which nine 
former NCAA Division I athletes were interviewed. Because return on investment is a contentious issue and the returns are difficult to identify, we opted for a humanistic, phenomenological approach (Markula \& Silk, 2011). That is, we sought to understand how former athletes made sense of their experiences and the returns they received; importantly, this meant the athletes could identify, in their own terms, what was a cost and what was return. Following Lincoln, Lynham, and Guba (2011), the interviewers positioned themselves as co-constructors of knowledge in offering heuristic devices such as "investment," "information," "risk," and "returns" with which the participants could affirm, discount, or negotiate based on their own perspectives. In this way, we aimed to give "investment" to the former athletes, so that they could deconstruct it, in a direct affront to popular discourse that gives the athlete to investment. Through this phenomenological perspective, the present study offers commentary on and compliments the NCAA's GOALS study (Growth, Opportunities, Aspirations and Learning of Students in college) first conducted in 2010 and then again in 2015 (NCAA, 2015c).

\section{Interview Guide}

A semi-structured interview guide was created and revised after two pilot interviews. Interview questions addressed whether participants believed their own student-athlete experience was an investment and what types of returns they received from that investment after college. We used Bourdieu's approach to convertible capital as a heuristic framework to prompt participants to think about the different ways they could have paid for and received returns from participation (social, economic, cultural, and physical costs and returns). Additional questions explored the notions of uncertainty, risk, and access to information related to their participation.

Given the humanistic and phenomenological design of this study, we prompted participants to answer questions by reflecting on their experiences. We also, as stated above, encouraged the participants to critically evaluate the concepts of investment and their relevance to college athletics and post-athletic life. For instance, all participants were asked a version of, "What do you think of evaluating college sport participation as an investment?"

\section{Sample Selection}

Initial participants were invited to join the study from the researchers' existing social networks and then snowball sampling was used to connect with additional participants. Participants were recruited and interviewed in semi-formal private settings until an exhaustive description (i.e., thematic saturation) was achieved (Creswell, 2007; Moustakas, 1994). Saturation was reached when emerging meaning units (i.e., "investment as cost," "coaches as holders and givers of information," etc.) became stable; in other words, new participants spoke to the same themes articulated with regards to different contexts (such as different sports, different life events, and unique subject-positions) (Creswell, 2007; Moustakas, 1994).

Participants were selected on the basis of having at least one-season of college sport experience (mean experience was 3.4 
years) and were at least one-year removed from college (mean time since participation was 8.0 years). The participant group was comprised of six women and three men of varying race and ethnicity who participated in a number of different sports (crosscountry (1), football (2), Nordic skiing (1), rowing (1), soccer (1), swimming (1), and track and field (2)) for schools geographically dispersed across the United States. Participants held a variety of athletic scholarships during their student-athlete tenure (full, partial, and nonscholarship/walk-on status), some passing through all types of scholarship. Three participants attempted to transition to the professional-level after college, although none were able to do so as their sole source of employment and all had withdrawn from professional competition at the time of the study.

Our participant group demonstrated considerable heterogeneity according to gender, ethnicity, sport, and scholarships. Given the epistemological framework and goals of this study, we feel this variability was important for acknowledging the multiple and subjective experiences of college athletes (Manning, 1997). However, there are two characteristics of the research sample that deserve reflection: overrepresentation of lower-profile sports and women athletes. We reflect on the implications of these over-representations in the conclusion, discussing how, precisely because of the composition of our sample, our findings are particularly well positioned to illuminate some current debates regarding college sport participation for some, but less so for others. For now note: of the 23 sports governed by the NCAA, more than half of the student-athlete population are women and the revenue sports (predominantly men's sports) are the clear minority (NCAA, 2015b). In general, we found that there was little difference between the responses provided by athletes in more visible sports than those in less publicized ones; the same was true between men and women. A possible explanation of this phenomena given during several of the interviews was that it was difficult for respondents to completely isolate their personal experiences from the greater social experience of living, training, and attending classes with other student-athletes (of varying demographics, sports, and athletic backgrounds). In sum, because our objectives in this project were idiographic in nature, avoiding nomothetic conclusions, we believe the final sample was appropriate for the task.

\section{Analysis}

Each interview was electronically recorded and transcribed by hand. Following Creswell's (2007) phenomenological approach, from these transcripts a list of significant statements was created, paying particular attention to non-repetitive, non-overlapping statements and giving each statement equal worth. Statements were grouped into themes and then a textural and structural description followed to describe what each participant experienced and how that experience occurred (Cresswell, 2007). The final description was constructed by reorganizing the coded material to form a credible representation of the cumulative narrative (Tracy, 2010) that preserved the authenticity of the participants' experiences. 


\section{College Sport as an Investment}

Research participants characterized participation in college sport as a personal investment, with real opportunity costs and risk, from which they expected a return. While ROI is discussed in the following section, here we focus on how college sport became an investment for the participants.

Although all of the former athletes were able to consider college sport participation as an investment, there were some nuances in why each athlete was pursuing this investment and what they hoped to get from it in return. Specifically, some, such as Participant 2, expressed a socio-economic need to attain a college scholarship:

I come from basically a single parent home. My mom pays for everything and I didn't want her to struggle for me to be in college. Also, I didn't want to get into debt, but that didn't turn out to be the case. I don't think I could have withdrawn voluntarily. I say that because I don't know how I would have paid for school. Had it not been for sports, I would probably have more debt than I do now. (Participant 2, Personal Communication, 2015) This perspective can be contrasted with those offered by other participants who pursued college sport for the value of competing and challenging himself or herself at the next level. Despite the apparent differences, each of our participants vocalized some combination of socio-economic need and competitive desire motivating their investment decision.

\section{Risk and Information}

While there was some variation in the goals among the former college athletes in this study, when speaking about the decision-making process itself, they all identified similar experiences and anxieties. Information and risk were identified as two important themes in the interviews.

Participants used information from family, coaches, or administrators to decide to invest in college sports. These informants told them that they could get a free or reduced-cost education while participating in a sport they enjoyed and at which they excelled. Many of these information sources were never participants in NCAA sports, meaning that their knowledge of what it is like to be a student-athlete was secondhand. It became clear through the interviews that many of the risks in college sports were not discussed with participants during their initial investment decision. For instance, Participant 2 explained how a lack of information about what it is really like to be a year-round student-athlete and some misinformation from her coach, lead her to make a decision that she later regretted:

I ended up having to take out student loans. I was given a full-ride scholarship to go to college and upon time to resign, my coach gave me the proposition that, "You know you're covered and you get government aid as well, would you be okay with us giving some of your money to another student-athlete to help them out?" I'm thinking I'd be covered, but I wasn't. I didn't realize that for collegiate athletes you only get paid for the school year, so over the summer, if you don't know how to manage your money, well you're basically struggling or you're taking out a student-loan. So I ended up giving up some of my scholarship. So I wouldn't 
have done that and I would have got more information about the process of what it means to be a full-ride athlete. (Participant 2, Personal Communication, 2015)

As Black (1986) posits, the validity and comprehensiveness of information is perhaps the riskiest component of any investment decision. That is, although information is proffered and accepted as expertise, it is sometimes simply erroneous data misconstrued as knowledge.

The most pervasive sources of information for our respondents were their coaches and athletic administrators. Some coaches used information to manipulate their athletes. In the case of Participant 4, the coach played on the uncertainty of scholarships and used their information superiority about whether certain athletes were replaceable:

At any track meet, if I didn't do well my coach wouldn't talk to me. I could feel a sense of anger; I could just sense it. On the bus ride home my coach would be like "if we don't get our act together we will lose our scholarships." I could have left [the team], but I wanted to finish school and I wanted to leave with a degree. (Participant 4, Personal Communication, 2015)

Similar tactics were reported by a number of participants whereby coaches used the threat of replacement and/or loss of scholarship to influence the level of commitment of their athletes. As a consequence, athletes felt pressure to put more time and effort into their athletic training and performances to ensure their spot on the team. For one of our respondents, the environment created by this malicious use of uncertainty and information asymmetry prompted her to transfer to a different university.

By fabricating the notion of an infinitely deep recruiting pool, coaches exaggerated their information superiority and accentuated the uncertainty of the returns perceived by their athletes. At other times, commitment to the team was used as a point of leverage. Calling attention to the importance of "the team" above individual interests, coaches and administrators devalued other academic, vocational, or extracurricular pursuits.

When benefits achieved through group success are over-emphasized, individual risks inherent in the pursuit of team goals can be masked (Alhakami \& Slovic, 1994; Finucane, Alhakami, Slovic, \& Johnson, 2000; Slovic, 1999). By exaggerating the economic value of an athletic scholarship or the social benefits of team sports (or conversely, demonstrating that these things can be taken away), coaches and administrators obscure the real tensions and opportunity costs of investing in athletics.

Six participants were required by their coaches or their practice schedules to select certain majors over others. They were also required to do so much training, travelling, and competing that their studies suffered considerably. Participant 9 expressed regret for buying into a team culture that treated academics as a second-class investment:

The reason I felt the academic stuff was worth letting go was because I felt that the only person I was letting down then was me. My grades, yeah they got me ineligible for a damn season, but the team still existed. There were other girls on the team and I believed enough in 
them to think that we would be ok.

(Participant 9, Personal

Communication, 2015)

What our interviews illuminated that other studies have not is the motivation to increase one's commitment to sport or team activities caused by the threat of losing the opportunity to seek a ROI from sport (i.e., losing a scholarship or being cut from the team). That is, the treatment of college athletics as an investment by their coaches, their administrators, their families, and popular discourse actually lead athletes to escalate their commitment.

Interestingly, the uncertainty of "opportunity lost" can even outweigh more concrete risks inherent in directing one's time away from other activities (e.g., committing to a team bonding activity instead of studying for a midterm). By investing time in sport or other team-based activities, student-athletes lost opportunities to realize value elsewhere. For instance, Participant 4 talked about the challenges she faced upon college graduation with little professional experience, stating, "A lot of my classmates were doing interviews and doing internships. I feel like what employers are looking for are people with experience and I really didn't have experience" (Participant 4, Personal Communication, 2015). Furthermore, when student-athletes rely on coaches and administrators as sole providers of information concerning the ideal management of their time, they allow for possible overrepresentation of athletic department interests in their personal investment strategies.

The manifest uncertainty in studentathlete time demands was also acutely corporealized in the form of physical injury, an obvious risk of sport participation. For instance, Participant 3's statement is characteristic of our respondents' experiences of injury:

So my first injury happened right at the beginning of my college career. I had a stress fractured third metatarsal that I didn't recognize and I ended up breaking that foot and missed the first three months of competition of my college career. It healed completely and I redshirted that year because of that. It was rapid rehab with pool workouts and running on the alternate gravity treadmill the whole time I was hurt, but that injury didn't linger with me at all. My next injury was a neuroma in my foot, like a swollen nerve. That one was a pretty quick fix. That was my junior year of college. Then my senior year I again had a stress fracture in my foot. It was a different bone. It happened right at the end of my indoor track season and I didn't notice it. I was running well and I was training really hard to have a good outdoor track season. I was actually on the track for my first practice when I broke it. It just broke. The experience rehabbing from that was a little different because as a senior, they gave me the boot and all that, but there was no rehab. Since I wasn't coming back they told me I didn't have to aggressively rehab that. (Participant 3, Personal Communication, 2015) Initially, physical injury and associated suffering might be interpreted as a cost of being a student-athlete. As Participant 3 described, injuries are an expected aspect of elite-level training and competition. 
However, what is also interesting for the current analysis of investment is the extent to which injuries and sufferings last after intercollegiate competition has ended. For example, Participant 2 reflected on her lasting injuries from being a college field athlete:

Javelin tore my elbow and shoulder up. One of my teammates had rotator cuff surgery. I didn't have to experience that, thank god, but the throbbing every now and again that I get in my arms, my lower back, I still don't even know how that happened. I got stuck bending over one day. And every now and then, more so when I'm up late, my back will hurt really bad. Ankles, that happens a lot. You'll roll your ankle and stuff. Shin splints, too. I actually injured my hip flexor, which I have issues with every now and again. A lot of that stuff, like beating up your body with weights and different events, puts your body into all these positions and motions. So not doing that anymore, you feel like every now and then it comes back and bothers you. (Participant 2, Personal Communication, 2015)

Thus, for some, the time spent as a premiere college athlete left them in permanent physical pain and created ongoing medical costs for which they are now solely responsible. Although none of the former athletes interviewed considered themselves to be seriously disabled as a result of their participation in college sports (others are not so fortunate), the approach to injury and rehabilitation reflects both institutional value on short-term labor viability and the use of information to encourage individual sacrifice in the name of athletic performance and/or team success. Long-term healing or preventative care were eschewed in favor of quick-fixes to keep student-athletes productive. In short, the risk of physical injury, uncertainty caused by time demands, and near-sighted institutional interests worked together to obfuscate student-athlete investment decisions and negatively impact personal ROI.

Those few who cited predominantly positive assessments of their college sport experience acknowledged the role of coaches and administrators who allowed for more autonomy in setting individual priorities and consideration of alternate sources of information. Participant 3's response was particularly indicative of how college representatives could contribute to positive student-athlete experiences and outcomes:

But my coach, I really believe this, cared more about my academic success than he did my athletic success. There was one time, I had an organic chemistry test and we had a meet with Texas Tech that weekend down in Lubbock. The coach was filling out the team and I was the number one $5 \mathrm{~K}$ guy who was supposed to go, and I said, "Hey coach, would it be alright if I didn't race this weekend and raced next weekend because I have this big organic chemistry test?" And he's like, "Yeah we can do that." I guess that's one of those moments that he recognized that I was concerned about the test and he probably sacrificed the team success for me. (Participant 3, Personal Communication, 2015) 
I came into college wanting to do biology pre-med and that's exactly what I ended up with. There is a physician there who serves on admissions who would come down to the athletic department and answer questions that anyone would have about what it takes to be accepted to medical school and what types of things they need to be doing. So I would say, because I was a student-athlete I got exposed to a good role model. (Participant 3, Personal Communication, 2015)

Participant 3 was able to maintain a balance between academics and athletics, search for information from multiple sources, and benefitted from support networks that appreciated the larger picture. In these cases, short-term athletic success and team objectives were occasionally suspended so attention could be turned to pressing needs in other areas. Additionally, scholarships and the more ambiguous notion of "opportunity lost" were not used as sources of leverage to influence student-athlete decisions.

\section{Equivocal Returns}

The former college athletes in this study recognized the importance of information and informants when, as a prospective student, they sought to decide on investing in sport participation and, as an enrolled student, they sought to escalate or deescalate their commitment. Some of these students experienced uncertainty as a result of asymmetries of information. Here we build on the initial analysis of investment in order to understand the returns that our participants achieved from college sport participation.
The majority of participants had difficulty describing the exact benefits of their involvement. For instance, Participant 6 clearly articulated how fallacious it is to assume that simply being a participant would result in returns:

I don't think my co-workers even know that I played sports. Even on my résumé, I don't know how long you keep that sort of thing on there. Maybe an employer could read into it and say, "You're a good team builder," but I don't know. I'm an underwriter for an insurance company, so my sport experience hasn't really done anything for me. (Participant 6, Personal Communication, 2015) Saying you played sport on your résumé is not what the NCAA is evoking when it promotes the benefits of athletic participation. Instead, the benefits are understood to come in the form of a degree_- "free" or at a reduced price_-and other intangible benefits more directly related to sport participation. Furthermore, the assumption is that these benefits are cumulative; that is, a college degree is good, but a free college degree (of any sort) is better.

The respondents, however, consistently separated their assessment of the benefits attributed to their education from those linked to their athletic participation. The majority of study participants cited athletics as being in conflict with academics. Respondents indicated that an overinvestment in athletics was a hindrance to the economic benefit they envisioned from having been a student-athlete.

The primary issue here seems to stem from the uncertainty of student-athlete time 
demands, as respondents were unable to devote enough time to academics in the face of athletic commitments. Repeatedly, respondents indicated they had to make compromises to secure their place on the team and/or athletic scholarship even though most were unable to maximize the benefit of the educational opportunity afforded by the scholarship. Though there was an overwhelmingly positive assessment of college sport participation as a "once in a lifetime" or "priceless" experience, most respondents indicated they would place more emphasis on academics if they had the chance to do it over again.

Furthermore, although the economic value of college sport participation is widely researched, in this study attributable economic outcomes were limited or nonexistent. Roughly half of our participants currently work in the sport industry (four), which would appear to reflect the benefits of participation. However, though they sought a career in sports because they had unique skills and experiences, their sport specialization also presented limitations. For our participants, working in the sport industry was both influenced by their love of sports forged over years of participation and the fact that they spent so much time participating in sports that they lacked the skills needed for other professions. Indeed, as Participant 4 demonstrated, these former athletes faced similar challenges to other underprepared graduates:

I just wish there was something after [graduation] so they can allow athletes to get on their feet, maybe financially, maybe a training camp. Myself, I feel like I was left hanging. When I left school, I felt like I would leave school and find a job easy. Thank god for my mother. I have a lot of friends that don't have jobs. They have that degree, but no experience. (Participant 4,

Personal Communication, 2015) Importantly, as Participant 4 clearly describes, the commitment to sport instead of other activities such as internships may even put college athletes in a more difficult position than their non-athlete peers. At a minimum, our interactions with former college student-athletes complicate the NCAA's position that participation prepares student-athletes to "go pro in something other than sports."

The acquisition of social capital is another possible source of utility for student-athletes. Below, Participant 9 reported that the social relationships formed during her participation played a significant role in her life after college:

I'm still friends with girls who were on the team, so you see it that way. Not just girls on my team, but other athletes. I'm still in touch with most of the baseball team from then, a few of the basketball players, some of the women's golf team. These are people that are still my friends. You're taking courses with them; you're sharing a weight room with people. The way the dorms were set up, and it's different now, they had baseball in this building, soccer in that building, and they faced each other with about 50 yards between the two. So we were really close with them. We saw it as this great opportunity to meet other people who did the same things we do. (Participant 9, Personal Communication, 2015) 
Here is evidence that sport participation provides lasting, intimate, social relationships. However, while all our participants celebrated this aspect of their post-athletic lives, many were unable to articulate exactly how their relationships benefitted them personally.

Importantly, much of the social capital attributed by participants was perceived only within networks of other college athletes with similar experiences. Participant 6 explained how the social relationships in her sport of rowing were predicated on their high school experience and college tenure:

Socially it was kind of difficult because it wasn't like your typical college sport where people are recruited. They had some people that were recruited, but other than that they had people who played different sports in high school because nobody really rows, at least not in Kansas. So socially it was difficult to break into that higher group. There was clearly a divide between the seniors and the freshmen. Then they had multiple strings. So they had people who had been rowing for a while and they were really good at it, and then they had people who had just played other sports. (Participant 6, Personal Communication, 2015) Although Participant 6 points out that her case was a unique example, evidence of social segregation in sport is well documented (DeLuca, 2013; Swanson, 2009). This observation is supported by Putnam (2000), who distinguished between two forms of social capital: bonding and bridging. Although researchers have shown that both may occur under certain circumstances (Beaudoin, 2011; Palmer \&
Thompson, 2007; Vermeulen \& Verweel, 2009), social capital formed during sporting interactions is most often characterized as intragroup "bonding" rather than intergroup "bridging" (Putnam, 2000; Putnam \& Goss, 2002). This is particularly salient in the current study, for where bonding triumphs, sport participation favors the creation of homogeneous relationships that could stifle career mobility and significantly restrict civic engagement (Coakley, 2011; Harvey, Lévesque, \& Donnelly, 2007). However, the excerpt from Participant 8 demonstrates how bonding and bridging can both occur, eventually resulting in new pathways in one's social network:

I had a great experience from my freshman year to my senior year. Thinking I was just going to go to school and get drafted by some team or something, but that wasn't the case.

Over time I met people and I met more people different from myself. Meeting more people exposed me to more things. I met one of my good friends and he actually gave me the opportunity to be on the radio and meet other guys. (Participant 8, Personal

Communication, 2015)

In Participant 8's case, "bonding" with his teammates gave him access to social networks beyond sport, which led to a job opportunity in radio and "bridged" his access to networks in the community of radio professionals.

Finally, it is worth reiterating that, despite the lack of measurable ROI, the majority of the respondents expressed being a student-athlete was of significant experiential value. Reflecting on the time 
spent as an athlete, they identified that the experience of competing at an elite-level, the prestige of being recognized as a varsity athlete, and belonging to an exclusive organization provided a sense of intrinsic value. Recognition of this benefit is a manifestation of cultural capital afforded by participation.

Upon closer analysis it was observed that the potency of this form of capital has a shelf-life and is not easily extended beyond college. Participant 6 was wrestling with the limits of cultural capital when she questioned the relevance of her athletic experience:

In the job market they look a lot more at education, but activities and things like that, I don't think they would place an NCAA team activity over a club sport or something organized where you are working with people. There's not an advantage I would say.

(Participant 6, Personal

Communication, 2015)

Moreover, when other respondents articulated the cultural value of their experience, they described it as limited or ambiguous. In turn, the cultural significance of having been a college student-athlete is only valuable when it is recognized by others and is often reduced to a passing curiosity. Several participants highlight the limited exchange value of cultural capital, acknowledging that though their status as former student-athletes may be "exotic", it is only useful as a cultural novelty.

\section{Coda}

In this paper, we set out to evaluate the verity of the claim that being a college athlete is an investment. The claim is a popular one, espoused by economists studying human capital, the popular press evaluating student debt, and NCAA commercials advertising college sport participation. At first glance, it seems as though our participants also shared this belief. They reflected on their studentathlete experience as an investment and believed that it should be understood that way by aspiring high school athletes.

Despite their conviction, we had difficulty qualifying the return on investment that these former athletes purportedly received. Furthermore, while our respondents had difficulty identifying the long-term benefits they received from being a student-athlete, they were consistent on one thing: the cost. Being a studentathlete requires a significant amount of money, time, and effort along with forgoing many other experiences and opportunities for self-development. Therefore, according to our participants, being a student-athlete must be an investment because it is so costly, not necessarily because it provides returns.

How do we make sense of the contradictory manner by which these former student-athletes reflect on their experiences? And how can we reconcile it with the NCAA's version of events, in which they promote the returns of being a student-athlete and, at best, neglect to publicize the costs? Being a student-athlete was, for all of our participants, an experience they would not trade for any other. In that sense, while they rationalized being a studentathlete in terms of investment, they recollected in terms of experience.

This is a key feature of sport that theories of human capital and political economy rarely elucidate (c.f., Gruneau, 
1979, as cited in Beamish, 1982; Ingham \& Hardy, 1984). When one plays sport, and in doing so puts one's body into motion with a lusory attitude, the outcomes are in excess of that which can be defined in bodily output. In other words, no matter how fully sporting goals might be appropriated for the production of capital, and no matter how completely sporting practice is reoriented to create investment, athletes, in this study at least, retain a sense of achievement which justifies their decision to participate in college athletics. For our respondents, their student-athlete experiences remain immensely enjoyable despite not having anything material to show for it.

We need to be very careful with this finding lest it be used to justify the continued over-extension of studentathletes. Instead, we argue that this finding should be interpreted as initial evidence for the need for a critical, research-driven evaluation of NCAA academic progress criteria. Specifically, we argue that our participants' reflections highlight the need for a clear delineation between short-term and long-term returns on investment.

Short-term returns from sport participation include internal rewards such as enjoyment and external rewards such as those provided by coaches and peers. According to our participants these returns were significant. However, these returns can also obscure the realities of long-term investment for college athletes. Our participants noted this happens in two ways. First, the thrill and enjoyment of competition itself led them to forgo educational opportunities. Second, and perhaps most importantly, coaches with short-term outlooks occasionally leveraged the respondents' perspective on the shortterm, causing the then student-athletes to forgo investments in the long-term.

When viewed in the context of the corporate university model promulgated by late capitalist economic rationality, this confounded investment paradigm is not much different than that facing non-athlete students. That is, all students presumably attend college as a form of investing for a better future. However, both the athlete and the student are valorized in their attendance, and both face an uncertain future with limited or skewed sources of information.

There are important differences, however, between athlete and non-athlete students. First, the athlete's body is of central importance to his or her investment. As Participants 2 and 3 showed, these bodies can be broken. And second, the student and the athlete are entwined in each other's attendance, meaning they play a symbiotic role in their conjoined exploitation. The student indebting himself to the workforce, is tied, by way of exuberant athletics fees, to the athlete who must forgo her desired major or sacrifice non-sporting social relationships in order to practice. Thus, it appears the myths surrounding the college athlete experience mirror similar falsehoods presented to nonathlete students, supporting the supposition that the corporate university model extends to all students (Giroux, 2014).

As noted in the introduction and method, our research-given an overrepresentation of lower-profile sports and women participants-is not as relevant for commenting on the investments of aspiring professional athletes. However, given that the NCAA (2015a) estimated the 
probability of collegiate athletes going pro to range from as low as $0.9 \%$ in women's basketball to as high as $8.6 \%$ in men's baseball, the college athlete who will not, or did not go professional is certainly worthy of sustained scholarly attention.

Nevertheless, we believe a similar humanistic, phenomenological method could be used for those athletes who have made or started careers playing sportsthey too deserve that the benefits of life after college not be taken-for-granted. Finally, with respect to our overrepresentation of women participants, the current findings add nuance to the oftassumed notion that women athletes perform better and graduate at a higher rate than their men counterparts (see for instance Leeds \& von Allmen, 2014).

In summary, while it may be necessary in the current climate of high performance amateur sport and the corporate university to treat college athletics as an investment, the theory of human capital cannot be used to explain this investment because studentathletes are not rational in the long-term (at least they are not permitted to be rational in the long-term). They enjoy competing, training with their peers, and holding a privileged status on campus. Furthermore, the entire support network created to ensure their success is designed to produce on-field performers and off-field "progressers" for four years-and only four years. The student-athlete is not an enterprise-of-the-self after all, despite the NCAA, academic, and popular discourse that has obfuscated this fact. 


\section{References}

Alhakami, A. S., \& Slovic, P. (1994). A psychological study of the inverse relationship between perceived risk and perceived benefit. Risk Analysis, 14(6), 1085-1096.

Aronowitz, S. (2000). The knowledge factory: Dismantling the corporate university and creating true higher learning. Boston: Beacon Press.

Baade, R. A., \& Matheson, V. A. (2001). Home run or wild pitch? Assessing the economic impact of Major League Baseball's All-Star Game. Journal of Sports Economics, 2(4), 307327.

Barron, J. M., Ewing, B. T., \& Waddell, G. R. (2000). The effects of high school athletic participation on education and labor market outcomes. Review of Economics and Statistics, 82(3), 409-421.

Bass, J. R., Newman, J. I., \& Giardina, M. D. (2012). Of victims and markets: The neoliberal university and the spectacle of civic branding. Cultural Studies $\Leftrightarrow$ Critical Methodologies, 12(4), 301-305.

Beamish, R. (1982). Sport and the logic of capitalism. In H. Cantelon \& R. Gruneau (Eds.), Sport, culture and the modern state. Toronto, Buffalo \& London: University of Toronto Press.

Beamon, K. K. (2008). "Used Goods": Former African American College Student-Athletes' Perception of Exploitation by Division I
Universities. The Journal of Negro Education, 352-364.

Beaudoin, C. E. (2011). News effects on bonding and bridging social capital: An empirical study relevant to ethnicity in the United States. Communication Research, 38, 155-178.

Becker, G. S. (1962). Investment in human capital: A theoretical analysis. The Journal of Political Economy, 9-49.

Black, F. (1986). Noise. The Journal of Finance, 41(3), 529-543.

Bourdieu, P. (1986). The forms of capital. In I. Szeman \& T. Kaposy (Eds.), Cultural theory: An anthology (pp. 8193). West Sussex, UK: WileyBlackwell.

Bourdieu, P. (1989). Social space and symbolic power. Sociological Theory, 7(1), 14-25.

Bourdieu, P. (2005). Principles of an economic anthropology. In N. J. Smelser \& R. Swedberg (Eds.), The handbook of economic sociology (pp. 75 89). Princeton, NJ: Princeton University Press. Callon, M., Lascoumes, P., \& Barthe, Y. (2009). Acting in an uncertain world: An essay on technical democracy (G. Burchell, Trans.) Cambridge, MA: MIT Press. (Original work published 2001) Coakley, J. (2006). The good father: Parental expectations and youth sports. Leisure Studies, 25(2), 153-163.

Coakley, J. (2011). Youth Sports What Counts as "Positive Development?". 
Journal of Sport \& Social Issues, 35(3), 306-324.

Coleman, J. S. (1988). Social capital in the creation of human capital. American Journal of Sociology, S95-S120.

Creswell, J. W. (2003). Qualitative inquiry and research design: Choosing among five approaches (2nd ed.).

Thousand Oaks, CA: Sage.

Cusack, M. J. (2007). The Academic Progress Rate: Good PR, bad policy. The Chronicle of Higher Education, 54(11), 2.

DeLuca, J. R. (2013). Submersed in social segregation: The (re)production of social capital through swim club membership. Journal of Sport and Social Issues, $X(\mathrm{X}), 1-21$.

Duda, J. L., \& Tappe, M. K. (1988).

Predictors of personal investment in physical activity among middle-aged and older adults. Perceptual and Motor Skills, 66(2), 543-549.

Eide, E. R., \& Ronan, N. (2001). Is participation in high school athletics an investment or a consumption good?: Evidence from high school and beyond. Economics of Education Review, 20(5), 431-442.

Ericsson, K. A. (2007). Deliberate practice and the modifiability of body and mind: Toward a science of the structure and acquisition of expert and elite performance. International Journal of Sport Psychology, 38(1), 4-34.

Ericsson, K. A., Krampe, R. T., \& TeschRömer, C. (1993). The role of deliberate practice in the acquisition of expert performance. Psychological Review, 100(3), 363.

Ewing, B. T. (1995). High school athletics and the wages of black males. The Review of Black Political Economy, 24(1), 65-78.

Ewing, B. T. (1998). Athletes and work. Economics Letters, 59(1), 113-117.

Ewing, B. T. (2007). The labor market effects of high school athletic participation evidence from wage and fringe benefit differentials. Journal of Sports Economics, 8(3), 255-265.

Finucane, M. L., Alhakami, A., Slovic, P., \& Johnson, S. M. (2000). The affect heuristic in judgments of risks and benefits. Journal of Behavioral Decision Making, 13(1), 1-17.

Forrest, D., \& Simmons, R. (2003). Sport and gambling. Oxford Review of Economic Policy, 19(4), 598-611.

Fort, R., \& Quirk, J. (1995). Crosssubsidization, incentives, and outcomes in professional team sports leagues. Journal of Economic Literature, 1265-1299.

Foucault, M. (2008). The birth of bio-politics: Lectures at the College de France 19781979. M. Senellart (Ed.). (G. Burchell, Trans.) New York: Picador. (Original work published 2004)

Fox, K. R. (1997). The physical self: From motivation to well-being. Champaign, IL: Human Kinetics. 
Fox, K. R. (1999). The influence of physical activity on mental well-being. Public Health Nutrition, 2(3a), 411-418.

French, P. A. (2004). Ethics and college sports: Ethics, sports, and the university. Lanham, MD: Rowman \& Littlefield.

Giroux, H. A. (2007). The university in chains: Confronting the military-industrial-academic complex. Boulder: Paradigm Publishers.

Giroux, H.A. (2013). On critical pedagogy. New York: Bloomsbury.

Giroux, H.A. (2014). Neoliberalism's war on higher education. Chicago: Haymarket Books.

Grant, A. M. (2012). ROI is a poor measure of coaching success: towards a more holistic approach using a well-being and engagement framework. Coaching: An International Journal of Theory, Research and Practice, 5(2), 74-85.

Gray-Lee, J. W., \& Granzin, K. L. (1997).

Understanding participation in exercise and sport: An extended application of personal investment theory. Journal of Sport Behavior, 20(1), 37.

Harvey, J., Lévesque, M., \& Donnelly, P. (2007). Sport volunteerism and social capital. Sociology of Sport Journal, 24, 206-223.

Hoffmann, R., Ging, L. C., \& Ramasamy, B. (2002). The socio-economic determinants of international soccer performance. Journal of Applied Economics, 5(2), 253-272.
Ingham, A., \& Hardy, S. (1984). Sport: Structuration, subjugation and hegemony. Theory, Culture \& Society, 2(2), 85-103.

Kids Play USA. (2015). Overview and cost of youth sports. Retrieved from http://kidsplayusafoundation.org/ov erview-and-cost-of-youth-sports

Kirkpatrick, D. L. (1977). Evaluating training programs: Evidence vs. proof. Training and Development Journal, 31(11), 9-12.

LaForge, L., \& Hodge, J. (2011). NCAA academic performance metrics: Implications for institutional policy and practice. The Journal of Higher Education, 82(2), 217-235.

Leeds, M. A., \& von Allmen, P. (2014). The Economics of Sport (5th edition). Boston: Pearson

Lincoln, Y. S., Lynham, S. A., \& Guba, E. G. (2011). Paradigmatic controversies, contradictions, and emerging confluences, revisited. In N. K. Denzin \& Y. S. Lincoln (Eds.) The SAGE Handbook of Qualitative Research. Los Angeles: Sage.

Long, J. E., \& Caudill, S. B. (1991). The impact of participation in intercollegiate athletics on income and graduation. The Review of Economics and Statistics, 525-531.

Manning, K. (1997). Authenticity in constructivist inquiry: Methodological considerations without prescription. Qualitative Inquiry, 3(1), 93-115 
Markula, P., \& Silk, M. (2011). Qualitative Research for Physical Culture. England: Palgrave Macmillan.

Miller, K. E., \& Hoffman, J. H. (2009). Mental well-being and sport-related identities in college students. Sociology of Sport Journal, 26(2), 335.

Miller, P., \& Rose, N. (2008). Governing the present: Administering economic, social and personal life. Cambridge: Polity.

Moustakas, C. (1994). Phenomenological research methods. Thousand Oaks, CA: Sage.

NCAA. (2007). NCAA launches latest public service announcements, introduces new student-focuses website [Press release]. Retrieved from http:// fs.ncaa.org/Docs/PressArchi ve/2007/Announcements/NCAA\% 2BLaunches $\%$ 2BLatest $\%$ 2BPublic $\% 2$ BService $\% 2 B$ Announcements $\% 2 B I n$ troduces $\% 2 \mathrm{BNew} \% 2 \mathrm{BStudent-}$ Focused \%2BWebsite.html

NCAA. (2015a). Probability of competing in sports beyond high school. Retrieved from http://www.ncaa.org/about/resourc es/research/probability-competingbeyond-high-school

NCAA. (2015b). Current student-athletes. Retrieved from http://www.ncaa.org/studentathletes/current

NCAA. (2015c). GOALS study. Retrieved from

http://www.ncaa.org/about/resourc es/research/goals-study

Neale, W. C. (1964). The peculiar economics of professional sports: A contribution to the theory of the firm in sporting competition and in market competition. The Quarterly Journal of Economics, 1-14.

Newman, J. I. (2014). Sport without management. Journal of Sport Management, 28(6), 603-615.

Oriard, M. (2012). NCAA academic reform: History, context and challenges. Journal of Intercollegiate Sport, 5(1), 4-18.

Ostrow, A. (1984). Physical activity and the older adult: Psychological perspectives. Princeton University Press.

Palmer, C., \& Thompson, K. (2007). The paradoxes of football spectatorship: On field and online expressions of social capital among the "Grog Squad." Sociology of Sport Journal, 24, 187-205.

Phillips, J. J. (1997). Return on investment in training and performance improvement programs. Woburn, MA: ButterworthHeinemann.

Putnam, R. (2000). Bowling alone: Collapse and revival of American community. New York: Simon \& Schuster.

Putnam, R., \& Goss, K. A. (2002). Introduction. In R. Putnam (Ed.), Democracies in flux: The evolution of social capital in contemporary society (pp. 1-19). Oxford University Press.

Reinboth, M., \& Duda, J. L. (2006). Perceived motivational climate, need satisfaction and indices of well-being in team sports: A longitudinal perspective. Psychology of Sport and Exercise, 7(3), 269-286. 
Rosen, S., \& Sanderson, A. (2001). Labour markets in professional sports. The Economic Journal, 111(469), 47-68.

Sack, A. L., \& Thiel, R. (1979). College football and social mobility: A case study of Notre Dame football players. Sociology of Education, 60-66.

Schultz, T. W. (1961). Investment in human capital. The American economic review, 117.

Siegfried, J., \& Zimbalist, A. (2000). The economics of sports facilities and their communities. The Journal of Economic Perspectives, 95-114.

Slovic, P. (1999). Trust, emotion, sex, politics, and science: Surveying the risk-assessment battlefield. Risk Analysis, 19(4), 689-701.

Smith, R. A. (2011). Pay for play: A bistory of big-time college athletic reform. University of Illinois Press.

Smith, E. L., \& Serfass, P. E. (1981). Exercise and aging: The scientific basis. Hillside,NJ: Enslow.

Sperber, M. (2000). Beer and circus: How bigtime college sports has crippled undergraduate education. London: Macmillan.

Staurowsky, E. J. (2014). College athletes' rights in the age of the super conference: the case of the All Players United Campaign. Journal of Intercollegiate Sport, 7(1), 11-34.

Swanson, L. (2009). Soccer fields of cultural [re]production: Creating "good" boys in urban America. Sociology of Sport Journal, 26, 404-424.
Szymanski, S. (2003). The assessment: the economics of sport. Oxford Review of Economic Policy, 19(4), 467-477.

Tracy, S. J. (2010). Qualitative quality: Eight "big-tent" criteria for excellent qualitative research. Qualitative inquiry, 16(10), 837-851.

Tuchman, G. (2009). W annabe U: Inside the corporate university. Chicago: University of Chicago Press.

Vermeulen, J., \& Verweel, P. (2009). Participation in sport: Bonding and bridging as identity work. Sport in Society, 12, 1206-1219.

Wall, M., \& Côté, J. (2007). Developmental activities that lead to dropout and investment in sport. Physical Education and Sport Pedagogy, 12(1), 77-87.

Washburn, J. (2008). University, Inc.: The corporate corruption of higher education. New York: Basic Books.

Watterson, J. S. (2002). College football: History, spectacle, controversy. Baltimore, MD: The Johns Hopkins University Press.

Wolverton, B. (2007). Athletes Question Effectiveness of NCAA Rule. The Chronicle of Higher Education, 53(18), 33 Wolverton, B., Hallman, B., Shifflett, S., \& Kambhampati, S. (2015, November 15). The $\$ 10$-Billion Sports Tab. Retrieved December 3, 2015, from http://chronicle.com/interactives/nc aa-subsidies-main\#id=table_2014 Zuber, R. A., Gandar, J. M., \& Bowers, B. D. (1985). Beating the spread: Testing the efficiency of the gambling 
market for National Football League games. The Journal of Political Economy, 800-806. 
